\title{
P74. A Good Manufacturing Practice procedure to generate therapeutic numbers of highly pure anti-leukaemic virus-specific T-cells
}

\author{
MM van Loenen ${ }^{1 *}$, R de Boer ${ }^{1}$, E van Liempt ${ }^{1}$, RS Hagedoorn ${ }^{1}$, P Meij ${ }^{2}$, I Jedema', JHF Falkenburg ${ }^{1}$, \\ MHM Heemskerk'
}

From 1st Immunotherapy of Cancer Conference (ITOC1)

Munich, Germany. 12-14 March 2014

\section{Background}

Recently, we have started a clinical trial to treat patients with high risk acute leukaemia with a donor-derived HA-1-TCR transduced virus-specific T-cell product as early as 8 weeks and 14 weeks after allogeneic stem cell transplantation (allo-SCT). Donor derived Cytomegalovirus (CMV)- and Epstein Bar virus (EBV)-specific T-cells will be isolated using Streptamer based CliniMACS selection, and will be subsequently transduced at day 2 with the well-characterized anti-leukaemic HA-1TCR and infused 10-12 days later. Based on these welldefined specificities this T-cell product is predicted to result in a selective Graft versus Leukaemia (GvL) effect without Graft versus Host Disease (GvHD). Important study parameters are persistence of the $\mathrm{T}$-cell product, feasibility of generation of HA-1-TCR transduced virusspecific T-cells, and the number of events of acute GvHD.

\section{Material and methods}

To obtain therapeutic cell numbers, one of the inclusion criteria is presence in donor peripheral blood of 1 or 2 virus-specific $\mathrm{T}$-cell population with a frequency of $\geq 0.05 \%$ of T-cells. MHC-Streptamers will be used to isolate 1 or 2 virus-specific T-cell populations from donor leukocytes. MHC-Streptamer incubation will result in binding of the TCR of the virus-specific T-cells of interest to the specific peptide presented by the MHC molecule on the Streptamers. Next to allowing selection of $\mathrm{T}$-cells of interest, this binding will also result in specific stimulation allowing subsequent transduction with the
HA-1-TCR. The process of isolation of pure populations of virus-specific T-cells and transduction with good manufacturing practice (GMP)-grade retroviral supernatant encoding the HA-1-TCR has been validated with 4 large scale test procedures in the cleanroom. To pass the in process (IP) testing, $\mathrm{T}$-cells needed to be $\geq 50 \%$ pure for the respective virus-specific tetramer directly after Streptamer isolation. In addition, after transduction and subsequent culturing $\mathrm{T}$-cells need to be $\geq 60 \%$ antigenspecific, as measured with virus- and HA-1-tetramers. Moreover, transduction efficiency of $\geq 5 \%$ as measured with HA-1-tetramers is a prerequisite.

\section{Results}

All HA-1-TCR td virus-specific T-cell products met the criteria for IP testing and quality control testing. They contained $>90 \%$ antigen-specific T-cells and $>10 \%$ HA- 1 tetramer positive T-cells. Moreover, all HA-1-TCR td virus-specific $\mathrm{T}$-cell products were highly reactive against HA-1-positive leukaemic cells.

\section{Conclusions}

Here, we present a GMP-grade procedure to generate in a short culture period of less than 2 weeks therapeutically relevant numbers of defined antigen-specific and highly anti-leukaemia reactive $\mathrm{T}$-cells.

\footnotetext{
Authors' details

${ }^{1}$ Leiden University Medical Center, Hematology, Leiden, the Netherlands. 2Leiden University Medical Center, Clinical Pharmacy and Toxicology, Leiden, the Netherlands.
} 
doi:10.1186/2051-1426-2-S2-P48

Cite this article as: van Loenen et al.: P74. A Good Manufacturing

Practice procedure to generate therapeutic numbers of highly pure

anti-leukaemic virus-specific T-cells. Journal for ImmunoTherapy of Cancer 2014 2(Suppl 2):P48.

Submit your next manuscript to BioMed Central and take full advantage of:

- Convenient online submission

- Thorough peer review

- No space constraints or color figure charges

- Immediate publication on acceptance

- Inclusion in PubMed, CAS, Scopus and Google Scholar

- Research which is freely available for redistribution 